\title{
MASTER
}

\section{The Potential Impacts on Aquatic Ecosystems from the Release of Trace Elements in Geothermal Fluids}

\author{
R. M. Cushman \\ S. G. Hildebrand \\ R. W. Brocksen
}

Environmental Sciences Division

Publication No. 1097

\section{OAK RIDGE NATIONAL LABORATORY}




\section{DISCLAIMER}

This report was prepared as an account of work sponsored by an agency of the United States Government. Neither the United States Government nor any agency Thereof, nor any of their employees, makes any warranty, express or implied, or assumes any legal liability or responsibility for the accuracy, completeness, or usefulness of any information, apparatus, product, or process disclosed, or represents that its use would not infringe privately owned rights. Reference herein to any specific commercial product, process, or service by trade name, trademark, manufacturer, or otherwise does not necessarily constitute or imply its endorsement, recommendation, or favoring by the United States Government or any agency thereof. The views and opinions of authors expressed herein do not necessarily state or reflect those of the United States Government or any agency thereof. 


\section{DISCLAIMER}

Portions of this document may be illegible in electronic image products. Images are produced from the best available original document. 


\section{Printed in the United States of America. Available from National Technical Information Service \\ U.S. Department of Commerce 5285 Port Royal Road, Springfield, Virginia 22161 \\ Price: Printed Copy $\$ 4.50$; Microfiche $\$ 3.00$}

This report was prepared as an account of work sponsored by the United States Government. Neither the United States nor the Energy Research and Development Administration, nor any of their employees, nor any of their contractors, subcontractors, or their employees, makes any warranty, express or implied, or assumes any legal liability or responsibility for the accuracy, completeness or usefulness of any information, apparatus, product or process disclosed, or represents that its use would not infringe privately owned rights. 
Contract No. W-7405-eng-26

THE POTENTIAL IMPACTS ON AQUATIC ECOSYSTEMS FROM THE RELEASE OF TRACE ELEMENTS IN GEOTHERMAL FLUIDS ${ }^{1,2}$

R. M. Cushman, S. G. Hildebrand, and R. W. Brocksen

Environmental Sciences Division

Publication No. 1097

Date Pub11shed - October 1977

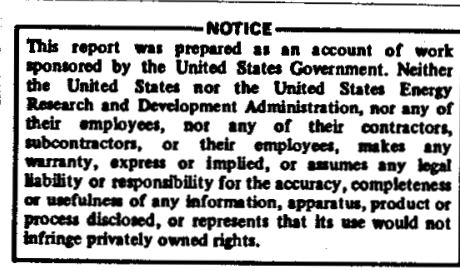

OAK RIDGE NATIONAL LABORATORY

Oak Ridge, Tennessee 37830

operated by

UNION CARBIDE CORPORATION

for the

DEPARTMENT OF ENERGY 
. 


\section{ABSTRACT}

CUSHMAN, R. M., S. G. HILDEBRAND, and R. W. BROCKSEN. 1977. The potential impacts on aquatic ecosystems from the release of trace elements in geothermal fluids. ORNL/TM6057. Oak Ridge National Laboratory, Oak Ridge, Tennessee. $30 \mathrm{pp}$.

Geothermal energy will likely constitute an increasing percentage of our nation's future energy "mix," both for electrical and nonelectrical uses. Associated with the exploitation of geothermal resources is the handling and disposal of fluids which contain a wide variety of potentially toxic trace elements. We present analyses of 14 trace elements found in hydrothermal fluids from various geothermal reservoirs in the western United States. The concentrations of these elements vary over orders of magnitude between reservoirs. Potential impacts are conservatively assessed on the basis of (1) toxicity to freshwater biota, and (2) bioaccumulation in food fish to the point where consumption might be hazardous to human health. Trace element concentrations generally range from benign levels to levels which might prove toxic to freshwater biota and contaminate food fisheries. We stress the need for site-specific analyses and careful handling of geothermal fluids in order to minimize potential impacts. 
. 


\section{TABLE OF CONTENTS}

Page

ABSTRACT .......................... . . i . . . . . . . .

LIST OF TABLES ........................ . . vii

INTRODUCTION ............................ 1

METHODS . . . . . . . . . . . . . . . . . 6

RESULTS . . . . . . . . . . . . . . . . 8

DISCUSSION . . . . . . . . . . . . . . . 10

LITERATURE CITED . . . . . . . . . . . . . . . 15 


\section{LIST OF TABLES}

Table $\quad$ Page

1 Potential none lectric uses of geothermal energy ..... 2

2 Reported trace element constituents and total dissolved solids (TDS) in selected hydrothermal fluids of the United States (a11 concentrations in $\mathrm{mg} / 1 ; \mathrm{nr}=$ not reported) .................... 5

3 Calculations of potential toxicity and bioaccumulation of trace elements in hydrothermal fluids. $B F=$ bioaccumulation $f$ actor, DWS $=$ drinking water standard .... 9

4 Surmary of trace elements in hydrothermal fluids that have a potential for toxicity or bioaccumulation hazard in aquatic ecosystems ........... 12 


\section{INTRODUCTION}

Recently, increased attention has been given to the potential utilization of geothermal energy for a variety of purposes, both in the generation of electrical power as well as a variety of nonelectrical uses. Economic and theoretical estimates of the potential capabilities of geothermal utilization vary widely. In the area of electrical production alone, projections of geothermally produced electrical capacity for the United States within the next 50 years vary from $1000 \mathrm{MW}$ to $440,000 \mathrm{MW}$ (Berman, 1975), representing $0.05 \%$ to $22 \%$ of the Nation's $2,000,000-\mathrm{MW}$ total electrical capacity projected for the year 2000 (Beall et a1., 1974). Geothermal generation of electricity is seen as attractive from the standpoint of economics, because the costs of capital equipment and "fuel" are lower than with many other forms of production. In comparison with nuclear or coal, where mining, processing, and generation occur at widely separated sites, environmental protection appears to be more easily assumed because the "fuel cycle" is confined to the site. In addition, public acceptability appears more likely than for most other technologies because geothermal energy is comonly regarded as clean, and apparently does not elicit the concerns for safety which accompany nuclear energy (Sma11, 1973).

Process heat uses of geothermal fluids (as well as the direct application of the fluids) for irrigation, aquaculture, and hydroponics are among the diverse nonelectrical uses suggested for geothermal energy (Table 1). Peterson and El-Ramly (1976) have estimated that nonelectrical uses presently account for less than $4 \%$ of exploited 
Table 1. Potential nonelectric uses of geothermal energy

1. Residential and Commercial Climate Control

a) Heating

1) District space heating (central control)

2) Space heating (single unit)

3) Hot-water service (all of above for homes, schools, hotels, hospitals, factories, clinics, farm buildings, etc.)

b) Cooling

1) Air conditioning (homes, hotels, factories, etc.)

2. Agricultural and Related Uses

a) Hot-water irrigation

1) Crop spraying

2) Soil warming

b) Greenhouses and hothouses

c) Animal husbandry
1) Egg incubation
2) Poultry
3) Swine
4) Dairy farms
5) Slaughterhouse operations

d) Aquacul ture

3. Industrial Processes

a) Chemical recovery
1) Carbon dioxide
2) Lithium
3) Sodium chloride
4) Calcium chloride
5) Borax
6) Iodine
7) Boric acid
8) Bromine
9) Hydrogen sulfide
10) Sulfur
ii) Magnesium
12) Magnesium sulfate

b) Chemical processing

1) Synthetic rubber

2) Paper manufacturing

3) Viscose rayon manufacturing

4) Metallurgical processes

5) Sulfur Frasch mining

c) Food related products
1) Protein manufacture
2) Dry curing of tea
3) Rice parboiling
4) Brewing and distillation
5) Sugar processing
6) Fermentation processes
7) Food processing and canning
8) Milk pasteurization

d) Drying and evaporation
1) Desalination of water
2) Seaweed drying
3) Textile drying
4) Lumber drying and seasoning
5) Seed drying
6) Peat drying

4. Balneology (health resorts and spas

SOURCE: Kunze and Richardson (1975) 
geothermal energy within the United States, while on a world-wide basis about two-thirds of exploited geothermal energy is used for nonelectrical purposes,

The Geothermal Steam Act of 1970, the Geothermal Energy Research, Development, and Demonstration Act of 1974, and the Federal Nonnuclear Energy Research and Development Act of 1974 promote the increased exploitation of geothermal resources in the United States. It can be expected that geothermal energy will provide an increasing percentage of our future national energy "mix." Legislation such as the National Environmental Policy Act of 1969, and other Federal, state, and local statutes, provide for the protection of environmental quality. Therefore, it is useful and appropriate to consider the potential impacts on aquatic resources, such as toxicity to biota and/or contamination of food fisheries caused by trace contaminants in hydrothermal fluids released to aquatic systems.

Release of geothermal fluids to aquatic environments, either by design or accident, could occur in many ways. A variety of techniques are used for the disposal of fluids at geothermal power plants, including direct release to surface waters, holding and evaporation in sumps, and injection back into deep reservoirs. The choice of disposal method is site-specific, depending on such factors as water quality protection, geothermal reservoir maintenance, ground subsidence potential, and engineering design and cost considerations. The transportation for utilization or disposal of geothermal fluids, such 
as through pipeline systems between wells and power plants or between wells and nonelectrical utilization facilities, may involve the piping of these fluids over distances of from tens of meters to tens of kilometers. In all of these processes, spills, sump overflows or dike breachings, equipment failure, or human oversight can result in the release of geothermal fluids and the ir constituent trace elements to streams, lakes, reservoirs, or other aquatic environments. In the Roosevelt Hot Springs (Utah) area, hydrothermal fluids were intentionally discharged into surface channels until damage to terrestrial vegetation became evident, at which point the practice was discontinued (Lenzer, Crosby, and Berge, 1977). Other situations in which the utilization design calls for surface release or use of hydrothermal fluids include land irrigation (Schmitt and Peterson, 1977), hydroponic greenhouse operations (Gutman, 1975), and aquaculture (Roberts, 1975).

Hydrothermal fluids from both liquid-dominated (hot water) and vapor-dominated (steam) reservoirs have been analyzed by several investigators and found to contain a variety of trace elements. Table 2 presents the analysis of 14 trace elements and total dissolved solids (TDS) from a selection of hydrothermal systems in the western United States and Alaska. Values of total dissolved solids range from hundreds to hundreds of thousands of milligrams per liter (mg/liter). Similarly, the concentrations of the elements in Table 2 range from less than one microgram per liter ( $\mu \mathrm{g} / \mathrm{liter}$ ) to thousands of $\mathrm{mg} / \mathrm{liter}$. The concentrations of these elements vary from region to region, from different wells within a region, and even with time from single wells. 


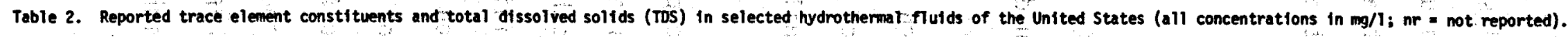

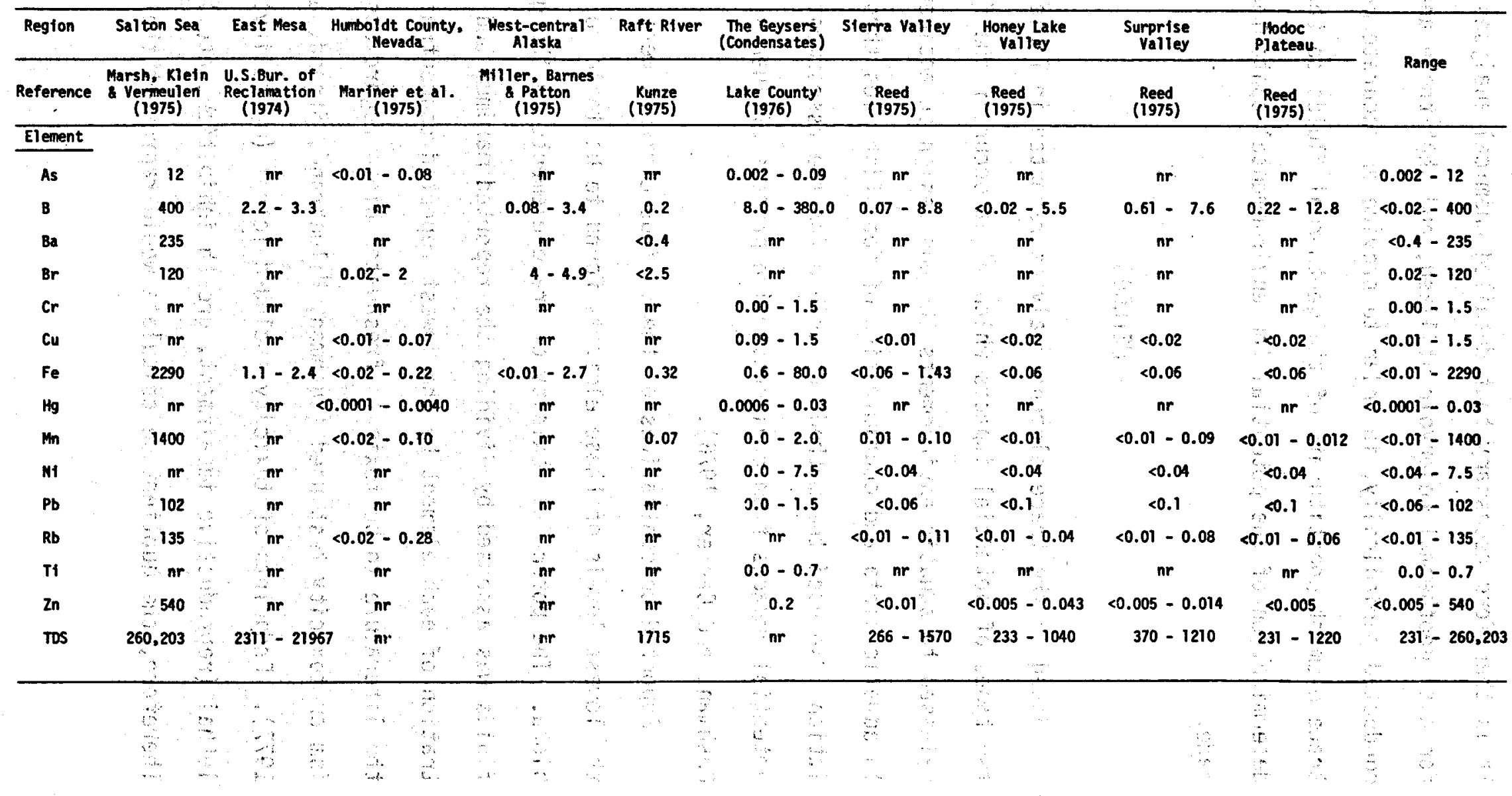


It is therefore necessary that detailed chemical analyses be performed for each geothermal reservoir utilized, and that these analyses be conducted periodically, in order to provide an accurate measure of the trace element constituents of the geothermal fluids so that an initial determination of the potential for environmental contamination can be made.

\section{METHODS}

Based on the trace element analyses reported in Table 2, we assessed two types of potential impacts which might occur if the fluids were released to aquatic environments through design or accident: toxicity to aquatic biota and contamination of food fisheries through bioaccumulation. We used the methods described for the assessment of these potential impacts from coal conversion process effluents (Hildebrand, Cushman, and Carter, 1976).

Reported concentrations of the various elements were compared with the lowest levels of these elements found to be toxic to freshwater biota. The potential toxicity of trace elements in the geothermal fluids was assessed by dividing the reported maximum and minimum concentration of each element by the lowest reported concentration found in the literature to be toxic to freshwater biota regardless of the organism or toxicity test used (Cushman, Hildebrand, Strand, and Anderson, 1977). Endpoints of toxicity included lethal (mortality) and sublethal (reproductive impairment, growth inhibition, etc.) effects. Therefore, the quotient we calculate would represent the highest 
anticipated toxicity effect for each concentration, and the higher the quotient the greater the possible effect.

In order to assess the potential for hazardous contamination of foods resulting from the bioaccumulation of trace elements by freshwater fish, we calculated the threshold concentration of the elements in freshwater at which fish would concentrate the elements to levels considered excessive for human consumption. We used the following relation, obtained from Dawson (1974):

$$
\text { threshold }(\mathrm{mg} / 1)=\frac{\text { DWS }(\mathrm{mg} / \text { liter }) \times 2 \text { (1iters water/day) }}{0.06(\mathrm{~kg} \text { fish/day) } \times \mathrm{BF}} \text {, }
$$

where:

$$
\begin{aligned}
\text { DWS } & =\text { drinking water standard } \\
B F & =\text { bioaccumulation factor for freshwater fish, }
\end{aligned}
$$

which simplifies to:

$$
\text { threshold (mg/liter) }=\frac{33 \text { DWS (mg/liter) }}{B F} \text {. }
$$

The factor used in calculating the threshold concentration for hazardous bioaccumulation for each element is based on the assumption that the only significant source of each element to humans is $0.06 \mathrm{~kg}$ of fish per day in the diet (USNRC, 1976). The maximum human daily intake of the element is set at the amount of the element which would be taken in through drinking two liters of water per day (USNRC, 1976) containing the element at a concentration equal to a drinking water standard. Estimates of the bioaccumulation factors for freshwater 
fish defined as $\frac{\text { concentration in fish (mg/kg wet wt) }}{\text { concentration in water (mg/liter) }}$ are available in the literature (Thompson et a1., 1972; Thompson et al., 1976). Reported bioaccumulation factors for fish may vary over orders of magnitude, even in similar situations (Vanderploeg et al, 1975). The values we used, however, are conservative and provide a reasonable basis for this preliminary assessment.

Reported maximum and minimum concentrations of trace elements in the geothermal fluids were divided by the calculated threshold concentration in order to provide a ratio for assessing the potential for hazardous bioaccumulation in freshwater fish. Where the ratio of the reported concentrations divided by either the toxic concentration or bioaccumulation threshold concentration had a value of one or more, this element was interpreted as potentially hazardous, with the potential for biological impact rated as low, medium, or high if the ratio

$$
\begin{gathered}
\frac{\text { concentration of element in hydrothermal fluid }}{\text { toxic concentration }} \\
\text { or } \\
\frac{\text { concentration of element in hydrothermal fluid }}{\text { bioaccumulation threshold concentration }}
\end{gathered}
$$

ranged between $1-100,100-10,000$, or $>10,000$, respectively.

\section{RESULTS}

Our analysis of the potential toxicity and bioaccumulation hazard of the trace elements found in hydrothermal fluids, based on the range of reported concentrations from Table 2, is sumarized for the 14 elements in Table 3. For most of the elements, the minimum reported 
Table 3. Calculation of potential toxicity and bioaccumulation of trace elements in hydrothermal fluids. BF = bioaccumulation factor, DWS = drinking water standard.

\begin{tabular}{|c|c|c|c|c|c|c|c|c|c|c|}
\hline Element & $\begin{array}{l}\text { Toxic } \\
\text { concentration }\end{array}$ & & $\begin{array}{l}\text { BF for } \\
\text { fish }\end{array}$ & Dus & $\begin{array}{c}\text { Threshold } \\
\text { bioaccumulati } \\
\text { concentratio } \\
\text { (33DWS/BF) } \\
\text { (mg/l) }\end{array}$ & & $\begin{array}{l}\text { Concentration of } \\
\text { in geothermal } \\
\vdots \\
\text { toxic concentr }\end{array}$ & $\begin{array}{l}\text { element } \\
\text { fluid } \\
\text { ation }\end{array}$ & & $\begin{array}{l}\text { Concentration of element } \\
\text { in geothermal fluid } \\
\div \\
\text { threshold bioaccumulation } \\
\text { concentration }\end{array}$ \\
\hline As & 0.022 & $\ldots$ & $333^{b}$ & $0.05^{d}$ & 0.005 & 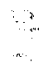 & $<1-550$ & & & $<1-2400$ \\
\hline B & 0.69 & & $1^{c}$ & $e^{e}$ & 33 & & $<1-580$ & $\because$ & & $<1-12$ \\
\hline $\mathrm{Ba}$. & 5.3 & 3 & $4^{b}$ & $1^{d}$ & 8.25 & & $<1-44$ & & & $<1-28$ \\
\hline $\mathrm{Br}$ & 0.18 & $\because$ & $417^{b}$ & $3.0^{f}$ & 0.24 & $\cdots$ & $<1-670$ & & 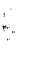 & $<1-500$ \\
\hline $\mathrm{Cr}$ & 0.005 & 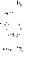 & $4000^{b}$ & $0.05^{d}$ & 0.0004 & $\therefore$ & $<1-300$ & & & $<1-3750$ \\
\hline $\mathrm{Cu}$ & 0.0006 & & $200^{b}$ & $0.1^{f}$ & 0.02 & & $?-2500$ & & & $<1-75$ \\
\hline $\mathrm{Fe}$ & 0.2 & 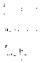 & $100^{b}$ & $0.3^{9}$ & 0.10 & & $<1-11,45$ & & & $<1-22,900$ \\
\hline $\mathrm{Hg}$ & 0.0001 & 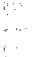 & $1000^{b}$ & $0.002^{d}$ & 0.0001 & & $\therefore<1-300$ & & & $<1-300$ \\
\hline Mn & 0.35 & & $660^{b}$ & $0.05^{9}$ & 0.003 & & $<1-4000$ & & & $?-470,000$ \\
\hline $\mathrm{Ni}$ & 0.03 & 3 & $100^{b}$ & $0.05^{f}$ & 0.02 & & $?-250$ & & & $?-375$ \\
\hline $\mathrm{Pb}$ & 0.007 & & $300^{b}$ & $0.05^{d}$ & 0.006 & & $?-14,60$ & & & $?-17,000$ \\
\hline $\mathbf{R b}$ & 14.0 & & $2000^{b}$ & $5^{f}$ & 0.08 & $\theta$ & $<1-9.6$ & & & $<1-1690$ \\
\hline $\mathrm{Ti}$ & 2.0 & $\therefore$ & $1000^{b}$ & $0.1^{f}$ & 0.003 & $\cdots$ & $<1$ & 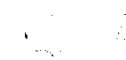 & & $<1-230$ \\
\hline - $\mathbf{Z n}$ & 0.01 & & $8500^{b}$ & $5^{9}$ & 0.02 & $\cdots$ & $<1-54,00$ & & & $<1-27,000$ \\
\hline & & & & & & 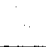 & $\therefore$ & & & \\
\hline
\end{tabular}

${ }_{b}^{a}$ Cushman, Hildebrand, Strand, and Anderson (1977)

Thompson et al. (1972)

Thompson et al. (1976)

Federal Register (1975)

Eederal Water Pollution Control Administration (1968)

Dawson (1974)

U.S.P.H.S. (1962) 
concentration was found to be below both toxic concentrations and concentrations with potential significance for contamination of food fisheries via bioaccumulation. That is, the ratios

$$
\begin{gathered}
\frac{\text { concentration of element in hydrothermal fluid }}{\text { toxic concentration }} \\
\text { and } \\
\text { concentration of element in hydrothermal fluid } \\
\text { bioaccumulation threshold concentration }
\end{gathered}
$$

calculated and presented in Table 3 were less than one.

At the maximum reported concentrations of the elements in hydrothermal fluids, however, only one element, titanium $(T i)$ was observed at a concentration below the known toxic level, while the other thirteen elements were found at toxic levels, with ratios ranging from 9.6 (Rb) to $54,000(\mathrm{Zn})$ (Table 3). All 14 elements we considered, when at maximum reported concentration, were found to present a potential bioaccumulation hazard, with ratios ranging from 12 (B) to $470,000(\mathrm{Mn})$ (Table 3).

The assessment of the toxicological and bioaccumulation significance of nickel $(\mathrm{Ni})$ and lead $(\mathrm{Pb})$, the toxicological significance of copper $(\mathrm{Cu})$, and the bioaccumulation significance of manganese $(\mathrm{Mn})$ at their lowest concentrations was not possible because of the lack of sensitivity of the analytical chemistry methodology.

\section{DISCUSSION}

In assessing impacts on aquatic ecosystems or man's use of aquatic resources, our preliminary analys is suggests that all 14 trace elements 
considered in this paper warrant attention. This will be especially true as the exploitation of geothermal resources for electrical and/or nonelectrical purposes increases in this country and elsewhere in the world. - Toxicologically, $\mathrm{Zn}, \mathrm{Pb}, \cdots$ and $\mathrm{Fe}$ appear to have the highest impact potential; $\mathrm{As}, \mathrm{B}, \mathrm{Br}, \mathrm{Cr}, \mathrm{Cu}, \mathrm{Hg}, \mathrm{Mn}$, and $\mathrm{Ni}$ are of medium concern; and $\mathrm{Ba}$ and $\mathrm{Rb}$ have lower impact potential when found at the ir highest reported concentration (Table 4). In terms of possible bioaccumulation hazard in freshwater food fisheries, $\mathrm{Fe}, \mathrm{Mn}, \mathrm{Pb}$, and $\mathrm{Zn}$ appear to have the highest impact potential, $\mathrm{As}, \mathrm{Br}, \mathrm{Cr}, \mathrm{Hg}, \mathrm{Ni}, \mathrm{Rb}$, and $\mathrm{Ti}$ have medium impact potential; and $\mathrm{B}, \mathrm{Ba}$, and $\mathrm{CU}$ have lower impact potential (Table 4). Potential impacts of these elements at the ir lowest reported concentrations in hydrothermal fluids range from benign to medium, or unknown, according to our analysis (Table 4).

This analysis of potential toxicity and bioaccumulation of trace elements in hydrothermal fluids is preliminary and should not be construed as a prediction of impacts in all cases. Nevertheless, every element considered in this paper was found in concentrations which varied with time and with location, and these concentrations could be harmful in some instances. The significance and interpretation of trace element concentrations in natural waters is complex. The. availability and solubtlity of many elements will depend on such factors as the presence of organic chelators in the water, and on the $\mathrm{pH}$ and oxidation-reduction potential of the water (Morel, McDuff, and Morgan, 1973). Additionally, synergistic or additive effects are possible, particularly with geothermal fluids, because of the high 
Table 4. Summary of trace elements in hydrothermal fluids that have a potential for toxicity or bioaccumulation hazard in aquatic ecosystems

\begin{tabular}{|c|c|c|c|c|}
\hline \multirow[b]{2}{*}{ Element } & \multicolumn{2}{|c|}{ Potential toxicity } & \multicolumn{2}{|c|}{ Potential bioaccumulation hazard } \\
\hline & $\begin{array}{l}\text { Minimum } \\
\text { concentration } \\
\text { reported }\end{array}$ & $\begin{array}{l}\text { Maximum } \\
\text { concentration } \\
\text { reported }\end{array}$ & $\begin{array}{l}\text { Minimum } \\
\text { concentration } \\
\text { reported }\end{array}$ & $\begin{array}{l}\text { Maximum } \\
\text { concentration } \\
\text { reported }\end{array}$ \\
\hline As & NEE & Medium & NEE & Medium \\
\hline$B$ & NEE & Medium & NEE & Low \\
\hline 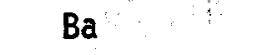 & NEE & Low & NEE & Low \\
\hline $\mathrm{Br}$ & NEE & Medium & NEE & Medium \\
\hline $\mathrm{Cr}$ & NEE & Medium & NEE & Medium \\
\hline $\mathrm{Cu}$ & $?$ & Medium & NEE & Low \\
\hline $\mathrm{Fe}$ & NEE & High & NEE & High \\
\hline $\mathrm{Hg}$ & NEE & Medium & NEE & Medium \\
\hline$M n$ & NEE & Medium & ? & High \\
\hline $\mathrm{Ni}$ & $?$ & Medium & ? & Medium \\
\hline $\mathrm{Pb}$ & $?$ & $\mathrm{High}$ & $?$ & High \\
\hline $\mathrm{Rb}$ & NEE & Low & NEE & Medium \\
\hline Ti & NEE & NEE & NEE & Medium \\
\hline $\mathrm{Zn}$ & NEE & High & NEE & High \\
\hline
\end{tabular}

Note: $\mathrm{NEE}=$ no expected effect (calculated ratio in Table 3 of $<1$ )

? = potential impact not determined because of insufficient analytical data Low potential = calculated ratio in Table 3 of 1-100

Medium potential = calculated ratio in Table 3 of 100-10,000

High potential = calculated ratio in Table 3 of $>10,000$ 
salinity in some cases (concentrations of TDS range into the hundreds of thousands of mg/liter), high heat content, and possible presence of many other toxic constituents. Thus, the actual assessment of the potential environmental impact of particular geothermal fluids will involve sitespecific characterizations of not only the organisms found in the local aquatic environment and the dilution of released fluids by the receiving waters but al so of the physical and chemical character of the geothermal fluids and receiving waters.

In the United States, most present and expected geothermal development is concentrated in the western states, where, in general, aquatic resources are scarce and highly valued, In all areas the geology is volcanic, and the water chemistry of surface waters is largely soft. Many trace elements have been found to be particularly toxic to aquatic biota in softer waters (Pickering and Henderson, 1964; Cairns and Scheier, 1957; Mount, 1966; Wurtz, 1962), and in such instances the potential for impact is clear. In the Geysers geothermal region in Cal if ornia, where electrical production from geothermal energy in the United States in currently centered, a kill of steelhead trout in Big Sulphur Creek has been attributed to a discharge of geothermal condensate. Boron, as boric acid, has been identified as a possible toxin in that situation (Axtmann and Peck, 1976).

Municipal water supplies may also be jeopardized by geothermal development. In Lake County, California, a proposed water supply, the Collayomi Reservoir, would be surrounded by planned geothermal development (Lake County, 1976). The necessity for environmental protection 
in such a case, where an inadvertent discharge of geothermal fluids could have a serious effect, is obvious.

In conclusion, the trace elements found in hydrothermal fluids range in concentration from benign levels to levels capable of causing toxic effects in aquatic biota and/or contaminating food fisheries to the point where the ir consumption would be potentially hazardous to humans. The variation of reported concentrations is such that periodic and sitespecific analyses are warranted. Our assessment of toxicity potential is based on a conservative methodology. As discussed earlier, trace element toxicity depends on a complex set of physical, chemical, and biological factors and interactions. The use of site-specific bioassays would be valuable in assessing the actual toxic characteristics of hydrothermal fluids from particular reservoirs. The integration of environmental protection measures into plans to utilize geothermal resources, whether for electrical or nonelectrical purposes, and the careful operation and maintenance of such facilities are mandated if aquatic environments are to be preserved, both as functioning and heal thy ecosystems and as resources for man. 


\section{LITERATURE CITED}

Axtmann, R. C., and L. B. Peck. 1976., Geothermal chemical engineering. AIChE Journal 22:817-828.

Beall, S. E., I. Spiewak, H. G. Arnold, H. W. McLain, E. S. Bettis, D. Scott, and B. Ahmed. 1974. An assessment of the environmental impact of alternative energy sources. ORNL-5024. Oak Ridge National Laboratory.

Berman, E. R. 1975. Geothermal Energy. Noyes Data Corporation, Park Ridge, New Jersey.

Cairns, J., Jr., and A. Scheier. 1957. The effects of temperature and hardness of water upon the toxicity of zinc to the common bluegill (Lepomis macrochirus Raf.). Not. Nat. Acad. Nat. Sci. Philadelphia 299.

Cushman, R. M., S. G. Hildebrand, R. H. Strand, and R. M. Anderson. 1977. The toxicity of 35 trace elements in coal to freshwater biota: A data base with automated retrieval capabilities. ORN/TM-5793. Oak Ridge National Laboratory.

Dawson, G. W. 1974. The chemical toxicity of elements. BNWL-1815. Batelle Pac ific Northwest Laboratories, Richl and, Washington.

Federal Register. 1975. National interim primary drinking water regulations. Fed. Regist. 40 (248), 24 December 1975.

Federal Water Poillution Control Administration. 1968. Water Quality Criteria: Report of the National Technical Advisory Committee to the Secretary of the Interior. Environmental Protection Agency, Washington, D.C. 
Gutman, P. W. 1975. Geothermal hydroponics. pp. 2217-2221. IN Proceedings of Second United Nations Symposium on the Development and Use of Geothermal Resources. Superintendent of Documents, Washington, D.C.

Hildebrand, S. G., R. M. Cushman, and J. A. Carter. 1976. The potential toxicity and bioaccumulation in aquatic systems of trace elements present in aqueous coal conversion effluents. IN Proceedings of 10th Annual Conference on Trace Substances in Environmental Health, University of Missouri, Columbia, June 8-10, 1976.

Kunze, J. F. 1975. Geothermal R\&D Project Report for Period Apri1 1, 1975 to June 30, 1975. ANCR-1247. Idaho National Engineering Laboratory, Idaho Falls.

Kunze, J. F., and A. S. Richardson. 1975. National Program Definition Study for the Non-Electrical Utilization of Geothermal Energy. ANCR-1214. Idaho National Engineering Laboratory, Idaho Falls. Lake County. 1976. Environmental Report, Dry Creek Exploration Project. County of Lake Planning Department, Lakeport, California. Lenzer, R. C., G. W. Crosby, and C. W. Berge. 1977. Recent exploration activities at Roosevelt Hot Springs Unit, Utah. Presented at Geothermal Resources Council Annual Meeting, San Diego, California, 9-11 May 1977.

Mariner, R. H., T. S. Presser, J. B. Rapp, and L. M. Willey. 1975. The Minor and Trace Elements, Gas, and Isotope Compositions of the Principal Hot Springs of Nevada and Oregon. U.S. Geol. Survey, Menlo Park, Cal ifornia. 
Marsh, A. R., III, G. Klein, and T. Vermeulen, 1975. Polymerization kinetics and equilibria of silicic acid in aqueous systems. LBL-4415. Lawrence Berkeley Laboratory, Berkeley, Cal if ornia. Miller, T. P., I. Barnes, and W. W. Patton, Jr. 1975. Geologic setting and chemical characteristics of hot springs in west-central Alaska. Jour. U. S. Geol. Survey 3(2):149-162.

Morel, F., R. E. McDuff, and J. J. Morgan. 1973. Interactions and chemostasis in aquatic chemical systems: Role of $\mathrm{pH}, \mathrm{pE}$, solubility, and complexation. IN Trace Metals and Metal-Organic Interactions in Natural Waters (P. C. Singer, ed.). Ann Arbor Science Publishers, Ann Arbor, Michigan.

Mount, D. I. 1966. The effect of total hardness and pH on the acute toxicity of zinc to fish. Int. J. Air Water Pollut. 10:49-56.

Peterson, R. E., and N. El-Ramly. 1976. The worldwide electric and nonelectric geothermal industry. IN Geothermal World Directory. K. R. Meadows, Ed. and Publ., Glendora, California.

Pickering, Q. H., and C. Henderson. 1964. The acute toxicity of some heavy metals to different species of warm water fishes. Proc. 19th Ind. Waste Conf. Part II, 49(2):578-591. Purdue University, Laf ayette, Indiana.

Reed, M. J. 1975. Chemistry of thermal water in selected geothermal areas of California. Report No. TR15. Cal if ornia Division of $0 i 1$ and Gas, Sacramento, California.

Roberts, P. A. 1975. Fish Culture Utilization of Geothermal Energy, ANCR-1220. Idaho National Engineering Laboratory, Idaho Falls. 
Schmitt, R. C., and H. B. Peterson. 1977. Utilizing Raft River geothermal water for irrigation. Presented at Geothermal Resources Council Annual Meeting, San Diego, California, May 9-11, 1977.

Small, H. 1973. Nature's Teakettle, Geothermal Information Services, West Covina, California.

Thompson, J. A. J., J. C. David, and R. E. Drew. 1976. Toxicity, uptake and survey studies of boron in the marine environment. Water Res. 10:869-875.

Thompson, S. E., C. A. Burton, D. J. Quinn, and Y. C. Ng. 1972. Concentration factors of chemical effluents in edible aquatic organisms. UCRL-50564 Rev. 1. Lawrence Livermore Laboratory, Livermore, California.

U. S. Bureau of Reclamation. 1974. Geothermal Resource Investigations, East Mesa Test Site, Imperial Valley, California, Status Report. U.S. Department of Interior, Washington, D.C.

U. S. Nuclear Regulatory Cormission (USNRC). 1976. Calculation of Annual Doses to Man from Routine Releases of Reactor Effluents for the Purpose of Evaluating Compliance with 10 CFR Part 50, Appendix I, Regulatory Guide 1.109 .

U. S. Public Health Service. 1962. The Public Health Service Drinking Water Standards (rev. 1962). Public Health Service Publication 956. Vanderploeg, H. A., D. C. Parzyck, W. H. Wilcox, J. R. Kercher, and S. V. Kaye. 1975. Bioaccumulation factors for radionuclides in freshwater biota. ORNL-5002. Oak Ridge National Laboratory. Wurtz, C. B.. 1962. Zinc effects on freshwater mollusks. Nautilus $76(2): 53-61$. 
INTERNAL DISTRIBUTION

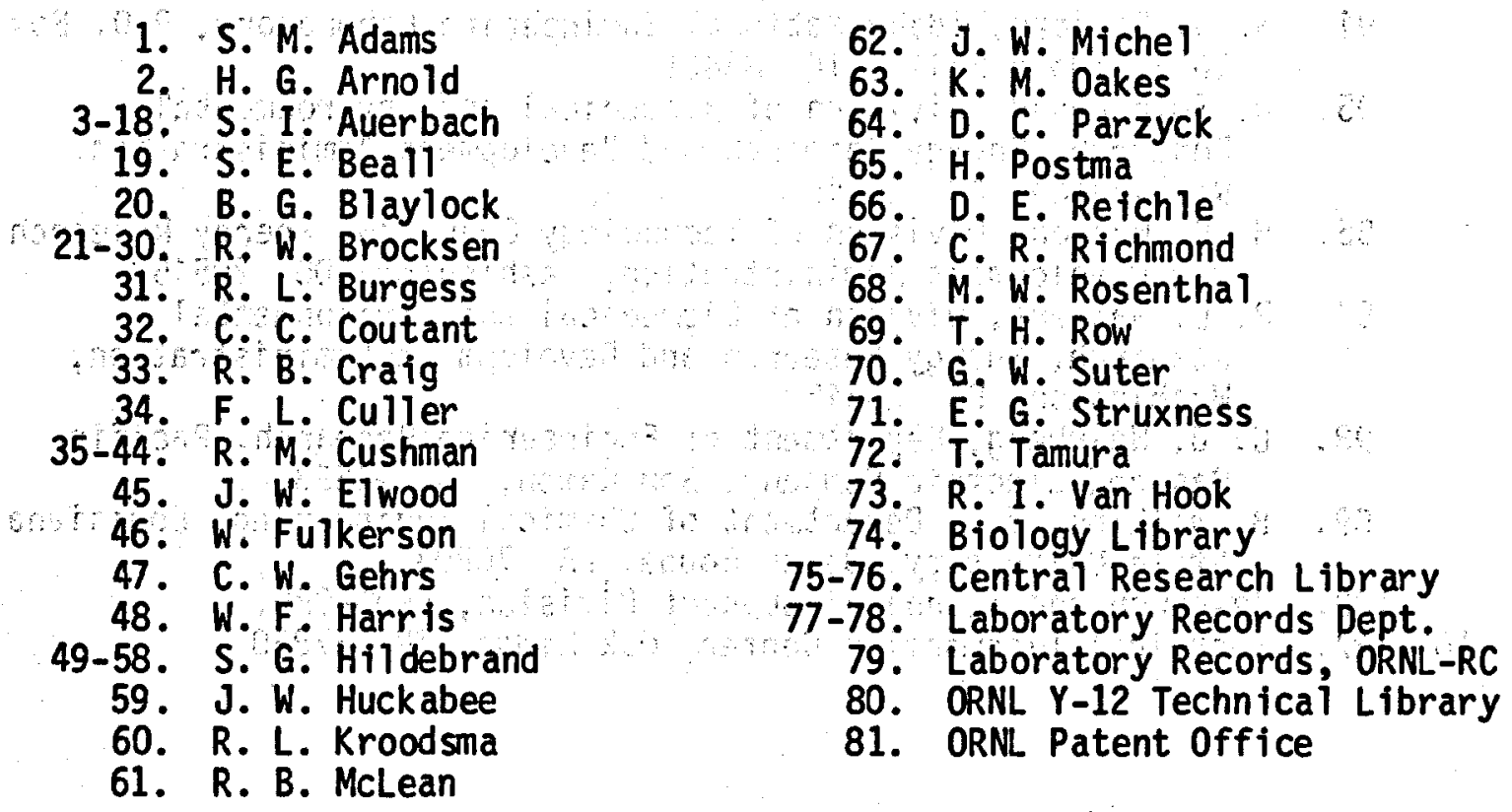

\section{EXTERNAL DISTRIBUTION}

82. L. R. Anspaugh, Lawrence Livermore Laboratory, P.0. Box 808, Livermore, CA 94550

83. R. A. Brechbil1, Environment and Safety Division, Energy Research and Development Admin istration, 1333 Broadway, Oakland, CA 94612

84. R. Chappel, Union 0il Company, P.0. Box 6854 Santa Rosa, CA 95406

85. J. Emig, Department of Fish and Game, P.0. Box 47, Yountville, CA 94599

86. T. Gustavson, Bureau of Economic Geology, University Station, Box X, Austin, TX 78712 .

87. J. R. Haugh, Division of Biomedical and Environmental Research, Energy Research and Development Administration, Washington, DC 20545

88. A. J. Jelacic, Division of Geothermal Energy, Energy Research and Development Admin istration, Washington; DC 20545

89. D. Lollock, Department of Fish and Game, The Resources Agency, 1416 Ninth St., Sacramento, CA 95814

90. R. R. Loose, Division of Geothermal Energy, Energy Research and Development Admin istration, Washington, DC 20545

91. R. Osterling, Landscape Horticulturist-Geothermal, Pac ific Gas and Electric Company, San Francisco, CA 94106

92. P. L. Phelps. Lawrence Livermore Laboratory, P.0. Box 808, Livermore, CA 94550 
93. V. H. Resh, Department of Entomology, University of California at Berkeley, Berkeley, CA 94720

94. S. G. Spencer, Idaho National Engineering Laboratory, P.0. Box 1625, Idaho Falls, ID 83401

95. J. Swinebroad, Division of Biomedical and Environmental Research, Energy Research and Development Admin istration, Washington, DC 20545

96. H. R. Wasson, Division of Technology Overview, Energy Research and Development Administration, Washington, DC 20545

97. R. L. Watters, Divison of Biomedical and Environmental Research, Energy Research and Development Admin istration, Washington, DC 20545

98. C. J. Weinberg, Department of Engineering Research, Pacific Gas and Electric Company, San Ramon, CA 94583

99. B. Wilkins, Jr., Department of Chemical Engineering, Louisiana State University, Baton Rouge, LA 70803

100. Research and Technical Support Division, ERDA-ORO.

101-127. Technical Information Center, Oak Ridge, TN 37830 